\title{
LEAD IN GRIFFON AND CINEREOUS VULTURES IN CENTRAL SPAIN: CORRELATIONS BETWEEN CLINICAL SIGNS AND BLOOD LEAD LEVELS
}

\author{
Julia Rodriguez-Ramos ${ }^{1}$, Valeria Gutierrez ${ }^{2}$, Ursula Höfle ${ }^{1,2}$, Rafael Mateo ${ }^{2}$, \\ Lidia Monsalve ${ }^{2}$, Elena Crespo ${ }^{3}$, And JuAn MANuel Blanco ${ }^{1}$ \\ ${ }^{1}$ Centro de Estudios de Rapaces Ibéricas CERI, Sevilleja de la Jara, Spain. \\ ${ }^{2}$ Instituto de Investigación en recursos Cinegéticos IREC, Ciudad Real, Spain. \\ ${ }^{3}$ CRFS, El Chaparillo, Ciudad Real, Spain.
}

\begin{abstract}
EXTENDED ABSTRACT.-As in other regions, vultures in Spain are often exposed to spent lead ammunition from carcasses of small and large game. This exposure may have increased after the ban on abandoning carcasses of domestic ruminants in the field due to the bovine spongiform encephalitis (BSE) crisis, both because the vultures consume hunting bag residues more frequently and because malnutrition may lead to mobilisation of lead stores (Iñigo and Atienza 2007). Although cases of clinical intoxication have been reported in numerous species including Griffon Vultures (Gyps fulvus) and Cinereous Vultures (Aegypius monachus) (Mateo et al. 1997, Mateo et al. 2003, Hernandez and Margalida 2008), little information on the potential correlation of blood lead levels and clinical signs and on potential subclinical effects of lead in vultures is available. Although other sources of lead may exist, in a study of live-trapped Griffon Vultures in southern Spain in which high blood lead levels were detected, the authors concluded that the ingestion of spent lead ammunition alone was responsible for the exposure (Garcia-Fernandez et al. 2005). An experimental study in Turkey Vultures (Cathartes aura) showed that there was great individual variation in susceptibility to lead, and that weakness and lack of coordination were present in most of the intoxicated birds, while only very high levels of lead produced lead toxicosis (Carpenter et al. 2003).
\end{abstract}

In this study, we analysed samples from vultures admitted to rehabilitation centers in South-central
Spain, comparing blood lead levels, clinical signs, and hematological data in order to determine any clinical/subclinical effect of exposure to high lead levels and the degree of exposure to which it might be related. In addition, our aim was to compare the blood lead levels obtained with the LeadCare ${ }^{\circledR}$ blood lead testing system (ESA Biosciences, Inc. Chelmsford, MA, USA), the system used in our rehabilitation center network for the rapid confirmation of clinical lead intoxications, with results obtained by standard laboratory methods.

Blood samples were taken from 56 Griffon, 13 Cinereous, and one Egyptian Vulture (Neophron percnopterus) upon admission to four different rehabilitation centers in central Spain throughout the years 2006 and 2007. Blood lead levels were measured with the LeadCare ${ }^{\circledR}$ device that uses anodic stripping voltammetry (ASV), and standard laboratory methods (ICP-inductively coupled plasma atomic emission spectrometry). Clinical signs suggestive of potential lead toxicosis included disorientation, ataxia and impaired landing, posterior paresis, and hematology ranged from a slightly increased polychromatic index to a severe hypochromic anemia.

A good correlation was observed between the results for blood lead levels obtained with the LeadCare ${ }^{\circledR}$ device and standard laboratory methods (Figure 1). One Griffon Vulture and the Egyptian Vulture were confirmed to have clinical lead intoxications. 


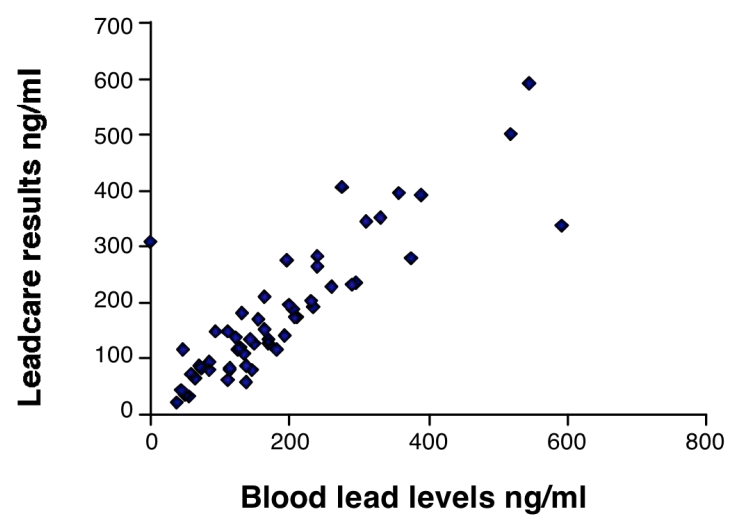

Figure 1. Correlation of blood lead levels obtained using the LeadCare ${ }^{\circledR}$ device and standard laboratory (ICP) methods.

While the Griffon Vulture also had severe traumatic lesions and was euthanized, the Egyptian Vulture was treated with oral and parenteral CalciumEDTA, and recovered. Mean blood lead levels among the other birds were $144.41 \mathrm{ng} / \mathrm{ml}$, with a range from 0.37 to $591.98 \mathrm{ng} / \mathrm{ml}$ in Eurasian Grif- fon Vultures, and mean of $70.07 \mathrm{ng} / \mathrm{ml}$ with a range from 0.75 to $512.16 \mathrm{ng} / \mathrm{ml}$ in Cinereous Vultures. Approximately $35 \%$ of the Griffon Vultures and $23 \%$ of the Cinereous Vultures tested had blood lead levels above $200 \mathrm{ng} / \mathrm{ml}$. Using nonparametric statistics we were not able to detect any correlation between clinical signs, hematological values, body condition, and blood lead levels in either of the species. Griffon Vultures appeared to be somewhat more exposed to lead than Cinereous Vultures, although this trend was not significant. In general, lead levels appeared to be higher in individuals admitted to the rehabilitation centers between midAugust and mid-February, coinciding with the large and small game hunting seasons, suggesting that spent lead ammunition alone is responsible for the uptake. To the best of the author's knowledge the lead intoxication in the Egyptian Vulture is the first description of lead intoxication in this species. Received 19 June 2008, accepted 27 October 2008.

Rodriguez-Ramos, J., V. Gutierrez, U. Höfle, R. Mateo, L. Monsalve, E. Crespo, and J. M. BlanCO. 2009. Lead in Griffon and Cinereous Vultures in Central Spain: Correlations between clinical signs and blood lead levels. Extended abstract in R. T. Watson, M. Fuller, M. Pokras, and W. G. Hunt (Eds.). Ingestion of Lead from Spent Ammunition: Implications for Wildlife and Humans. The Peregrine Fund, Boise, Idaho, USA. DOI 10.4080/ilsa.2009.0213

Key words: Ammunition, blood lead, clinical signs, hunting, lead, toxicosis, vultures.

\section{LiTERATURE Cited}

Carpenter, J. W., O. H. Pattee, S. H. Fritts, B. A. Rattner, S. N. Wiemeyer, J. A. Royle, AND M. N. SMITH. 2003. Experimental lead poisoning in Turkey Vultures. (Cathartes aura). Journal of Wildlife Diseases 39:96-104.

GARCIA-FERnANDEZ, A. J., E. MARTINEZ-LOPEZ, D. ROMERO, P. MARIA-MOJICA, A. GODINO, AND P. JiMENEZ. 2005. High levels of blood lead in Griffon Vultures (Gyps fulvus) from Cazorla Natural Park (southern Spain). Environmental Toxicology 20:459-463.

Hernández, M., AND A. MARgalida. 2008. Pesticide abuse in Europe: effects on the Cinereous Vulture (Aegypius monachus) population in Spain. Ecotoxicology 17:264-272.
IÑIgO, A., AND J. C. ATIENZA. 2007. Efectos del Reglamento 1774/2002 y las decisions adoptadas por la Comisión Europea en 2003 y 2005 sobre las aves necrófagas en la peninsula Ibérica y sus posibles soluciones. Official report to the European Comisión. SEO/BirdLife 15-06-2007.

MATEO, R., R. Molina, J. GRíFOls, AND R. GUITART. 1997. Lead poisoning in a free ranging Griffon Vulture (Gyps fulvus). Veterinary Record 140:47-48.

Mateo, R., M. Taggart, and A. A. Meharg. 2003. Lead and arsenic in bones of birds of prey from Spain. Environmental Pollution 126:10714. 